\title{
LXXIV. Observations on certain luminous meteors called falling stars
}

\section{Dr. T. Forster M.B. F.L.S.}

To cite this article: Dr. T. Forster M.B. F.L.S. (1821) LXXIV. Observations on certain luminous meteors called falling stars, Philosophical Magazine Series 1, 57:278, 418-420, DOI: 10.1080/14786442108652536

To link to this article: http://dx.doi.org/10.1080/14786442108652536

里 Published online: 27 Jul 2009.

Submit your article to this journal $\widetilde{ }$

ЏII Article views: 2

Q View related articles $₫$ 
is given to bodies, and the agency of rendering bodies infiammable is exerted at the opposite surface; and similar chemical effects are produced by negative electricity, and by the most refrangible rays of the solar beam. In general, in nature, the effects of the solar rays are very compounded. Healthy vegetation depends upon the presence of the solar beams, or of light; and whilst the heat gives fluidity and mobility to the vegetable juices, ehemical effects likewise are occasioned, oxygen is separated from them, and inflammable compounds formed. Plants deprived of light become white, and contain an excess of saccharine and aqueous particles; and flowers owe the variety of their hues to the influ $\rightarrow$ ence of the solar beams. Even animals require the presence of the rays of the sun, and their colours seem materially to depend upon the chemical infuence of these rays: a comparison between the polar and tropical animals, and between the parts of their bodies exposed, and those not exposed to light, shows the correctness of this opinion.

[To be continued.]

LXXIV. Olservations on certain luminous Meteors called Falling Stars. By Dr.T. Forster, M.B. F.L.S. ËC.

T Hartwell, E. Grinstead, June 2, 1821. Sir, - I observed this morning the Queries of Mr. J. Farey Sen., respecting Shooting Stars, as they are commonly called; and $I$ beg leave through your useful Magazine, to communicate such information and references to this subject as at present occur to me. I have for many years been an attentive observer of these curious meteors, and have noticed their peculiarities, and the particular states of the atmosphere in which they occur, with a view to ascertain their nature, and their relation to electrical phænomena.

On the large neteors, such, for example, as the great meteor of August 18, 1783, many treatises have been written, to which I have referred in a small work on atmospheric phænomena*. I have there alluded to the probable connexion between these phænomena, and the aërolites called Meteoric Stones, and to the curious observations of the late M. J. A. De Luc on this subject.

How far the smaller meteors called Falling Stars may be referable to similar causes, I am at present unable to say; neither would I venture, in the present stage of the inquiry, to adopt any particular hypothesis to explain them. The first object in meteorology, as in all sciences, must be to obtain an accurate series of facts well arranged. With this view, I have for upwards of

* Researches about atmospheric Phænomena, by T. Forster, London, $1814,2 d$ edition, p. 114.

thirteen 
thirteen years kept a journal of atmospherical phænomena, and at the same time have collected from the ancient writings of the Greek and Roman philosophers, whatever I could find that might bear on the object of my researches. For, disregarding all theories, the extreme accuracy of the observations of the Greek meteorologists renders them worthy of being referred to.

My own observations on falling stars have enabled me to divide them into three principal sorts. Of these three sorts, the largest are very brilliant and give considerable light: they move in curved as well as in straight lines, generally sloping downwards, and seldom very rapidly. The colour of their light is bright white, yellowish, or blueish, and very rarely copper coloured. They occur mostly on fine warm summer evenings when waneclouds abound; they seem to leave no train behind in general; when they do, it is under circumstances of peculiarity of atmosphere.

The next sort are much smaller, and occur in clear cold and frosty nights, both in winter and summer; and also in warm weather when east winds prevail. They shoot along with great rapidity, and leave no train, except such as I can refer to an effect produced on the retina of the eye by the rapid passage of the light; - -such a deceptio visus, for example, as Homer ascribes to the $80 \lambda \cdot \times 0 \sigma \times 60 v \varepsilon \gamma \times 05$.

The third sort of meteors are small in general like the last, but are distinguished by leaving a long train of light behind them, which lasts some seconds after the star is extinguished. 'This lind almost always forebode windy weather ; and when they occur, I have noticed that all meteors which happen on the same evening leave the aforesaid long whire tails behind them. These long tracts of white light are accurately noticed by Virgil in Geor. lib. i.

“ Sæpe etiam stellas, vento impendente, videbis

Præcipites colo labi, noctisque per umbram

Flammarum longos a tergo albescere tractus."

But Aratus the astronomical poet has given a still more beautiful and accurate description of them. The following passage occurs somewhere in the Diosemea:

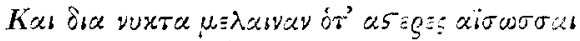

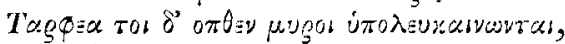

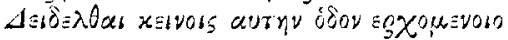

$$
\begin{aligned}
& \text { IIV }=u \mu a r 05 \text {. }
\end{aligned}
$$

Very copious observations on their appearance and indications may also be found in Plin. H. N. xviii. 35.-Aristot. Meteor. lib. i. c. 4.-Lucret. ii. 206, and v. 1190.-Seneca Nat. Quæst. i. 14. Refer also to Bertholon. Elect. Mct. Lyons, 178 , and $3 \mathrm{G} 2$ 
to that immense code of meteorology collected from all parts of Europe, and published in five quarto volumes by the Society of Meteorology formed and directed by the late Elector Palatine.

I have the honour to remain, sir, \&c.

To the Editor of the Phil. Mag.

T. Forster.

LXXV. Appendix to the Third Report of the Commissioners appointed by His Majesty to consider the Sulject of Weights and Measures.

$\mathrm{T}$

$T_{\text {n }}$ Commissioners having been furnished, by the kindness of the Hon. Charles C. C. Jenkinson, with the apparatus employed by the late Sir George Shuckburgh Evelyn, in the determination of the magnitude of the standard weights, and there being some doubt of the perfect accuracy of his method of measuring the capacity of the bodies employed, it was judged necessary to repeat that measurement with greater precautions; and the results of Captain Kater's experiments have afforded some slight corrections of the capacities in question.

The sic'es of Sir George Shuckburgh's cube were found by Captain Kater equal to $4.98911,4 \cdot 98934$, and 4.98935 inches; the diameter of the cylinder 3.99713 , and its length 5.99600 inches; and the diameter of the sphere 6.00759 inches. Hence the content of the cube appears to be $124 \cdot 1969$ inches; that of the cylinder 75.2395 ; and that of the sphere 113.5264 inches of Bird's Parliamentary Standard of 1760 , recommended in the last Report of the Commissioners, or of the Standard made by Troughton for Sir George Shuckburgh.

The difference of the weight of the cube in air at $62^{\circ}$, with the barometer at 29.0 , and in water at $60.2^{\circ}$, was $31381 \cdot 79$ grains; and, adding to this the weight of an equal bulk of the air at $62^{\prime \prime}$, which is $-\frac{1}{3} \frac{2}{3} \cdot \frac{2}{3}$ of that of the water, or 36.26 grains, and subtracting from it $\frac{1}{8} \cdot \frac{1}{3}$ of this, or $4 \cdot 26$ grains, the buoyancy of the brass weights, we obtain 31413.79 grains for the weight of the cube of water in a vacuum at $\left(60 \cdot 2^{\circ}\right.$. Now this cube is less than the supposed measure at the standard temperature of $62^{\circ}$, in the ratio of 1 to 1.0000567 , on account of the contraction of the brass; and the water is denser than at the standard temperature, according to Mr. Gilpin's experiments, in the ratio of .99998 to $\cdot 99981$, or of 1.00017 to 1 , the whole correction, for the difference of $1 \cdot 8^{\circ}$, being $\cdot 0001133$, or 3.55 grains, making S1410.24 for the weight of the cube of water in a vacuum at $62^{n}$; which, divided bv $124 \cdot 1969$, gives $252 \cdot 907$ for the weight of a cubic inch in Sir George Shuckburgh's grains. 